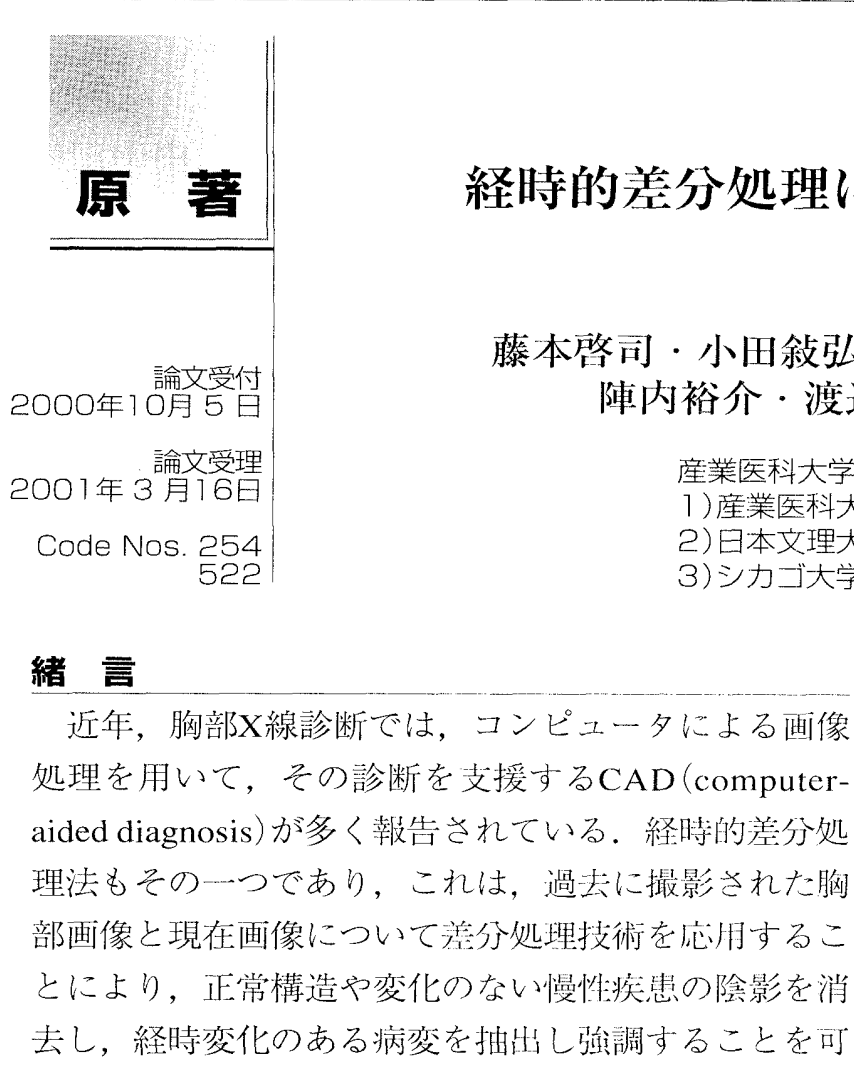

\title{
Effect of Image Data Compression on Temporal Subtraction Images in Chest Computed Radiography
}

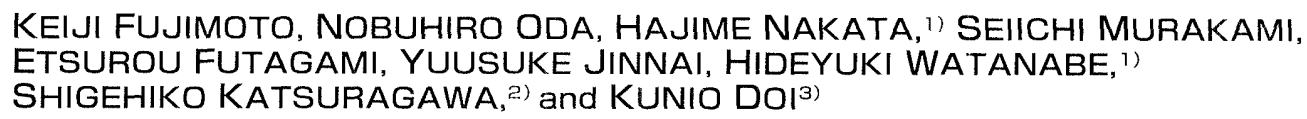

Department of Radiology, University Hospital of Occupational and Environmental Health

1) Department of Radiology, University of Occupational and Environmenta! Health.

School of Medicine

2) NBU General Research Center, Nippon Bunri University

3) Kurt Rossmann Laboratories for Radiologic Image Research. Department of Radiology, University of Chicago

Received Oct. 5, 2000; Revision accepted March 16, 2001; Code Nos. 254, 522

\section{Summary}

We investigated the effect of image data compression on temporal subtraction images in chest computed radiography $(C R)$. Subtraction images were obtained from current and previous CR chest images which were represented by either original data or 1/20 lossy compression data. One hundred clinical cases were employed in this study. The visual evaluation and histogram analysis indicated that the lossy compression did not affect the image quality in lung fields of the subtraction image. However, the standard deviation of pixel values in the mediastinum of the subtraction image obtained from compressed images was decreased probably because of smoothing in the image compression process. Therefore, we conclude that the use of compressed chest CR image data is suitable for temporal subtraction images.

Key words: Computer-aided diagnosis (CAD), Computed radiography $(C R)$, Temporal subtraction, Compressed image, Chest radiography 


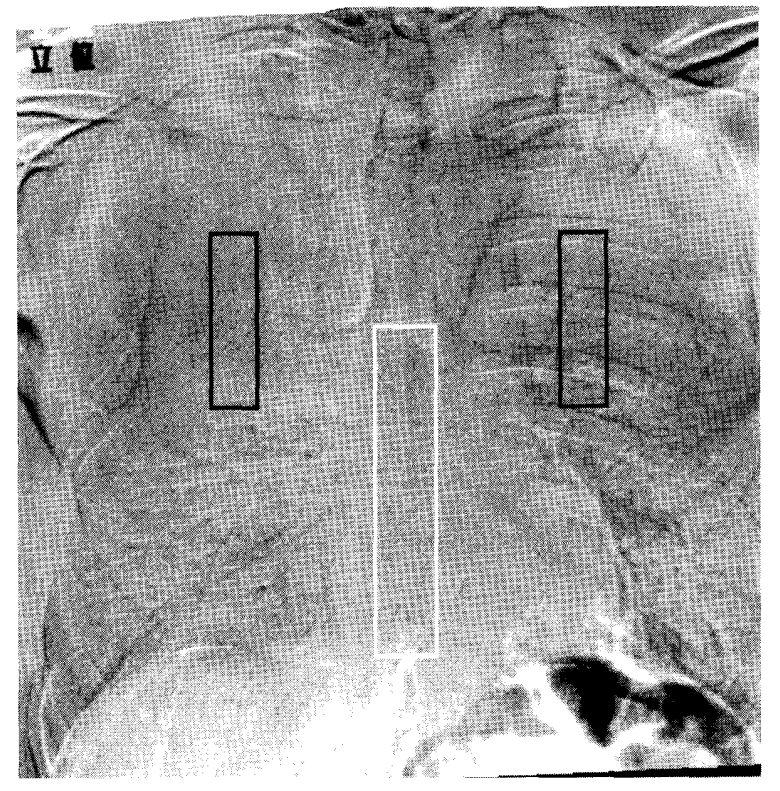

Fig. 1 Subtraction image with ROIs for histogram analysis and measurement of the standard deviation of pixel values.

縮画像でデー夕保管し6,7)，この圧縮された画像を経 時的差分画像処理に使用している, 5).

今回, 压絔なしの画像(オリジナル画像)および圧縮 された画像 $(1 / 20$ 非可逆圧絔画像)の胸部CR画像デー 夕を用いて, 経時的差分処理画像に及ぼすCRの非可 逆画像压縮の影響について検討を行ったので報告す る。

\section{1. 方 法}

1) X線撮影装置 (UB150-30B，株式会社島津製作所 製)はインバー夕力式で，X線管(CIRCLEX 0.6/ 1.2P 324 DK，株式会社島津製作所製)の焦点寸法 は $1.2 \mathrm{~mm} \times 1.2 \mathrm{~mm}$ を使用した。撮影条件は， $100 \mathrm{kV}$ の使用管電圧で，0.1 mm厚さの銅板を付加 フィルタとして (実効エネルギー $: 45 \mathrm{keV})^{8)}$, 管 電流は640mAでフォトタイマを使用した。グリ ッドは10：1，40strips/cmで，ブッキー撮影を行 い, SID (source image receptor distance)は $200 \mathrm{~cm}$ である、CRシステムは，立位撮影台専用夕イプ （FCR9501，富士写真フイルム株式会社製）を使 用した。イメージングプレート $(\mathrm{ST}-\mathrm{V}$, 富士写 真フィルム株式会社製) は， 2 種類のサイズ, $35 \mathrm{~cm} \times 35 \mathrm{~cm}$ および $35 \mathrm{~cm} \times 43 \mathrm{~cm}$ を用いた。マトリ クスサイズは，1,760×1,760および $1,760 \times 2,140$

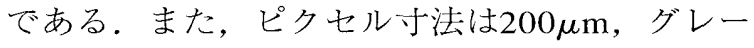
スケールの数は10bitであった，CRの画像デー 夕の取り込みは，2.1のL值に固定したマニュア ルモード(semi autoモード)で行った9).

2) 対象とした画像は, 産業医科大学病院において,
1999年 9 月から2000年1月の期間に撮影された 100 症例とした。100症例の内訳は，正常例が30 症例，肺炎(スリガラス影，網状影，線状影，索 状影) 28 症例，原発性肺癌20症例，転移性肺癌 6 症例，結節影 11 症例，線維症 1 症例，石疢化結 節 1 症例㧍よび胸水 3 症例であった。臨床の胸 部CR画像を用いてオリジナル画像の過去画像と 現在画像の差分処理を行った。同様に圧縮された 画像 $(1 / 20$ 非可逆圧縮画像)に対して差分画像処理 を行い，それぞれ100症例の経時的差分画像を得 た。実際には，撮影された胸部CR画像は，ネッ トワーク上でDICOMゲートウェイを介して，読 影室にあるワークステーション (O2，SGI社製)に 画像転送される。画像転送された過去画像と現在 画像は，単純間引きにより1/3に縮小された後， 差分画像処理を行い経時的差分画像が作られる。 したがって，差分画像のマトリクスサイズは，イ メージングプレートの大角拉よび半切サイズとも 586×586で，グレースケールの数は10bitである. なお，半切サイズの画像取り迟み時のマトリクス サイズ， $1,760 \times 2,140$ の画像デー夕は，横隔膜下 部に相当する下方の画像データを切り落として, 大角サイズでトリミングを行った。

3)過去および現在画像間の不整合に起因する経時的 差分画像のアーチファクトの程度を比較するため に，Fig. 1の黑枠に示すように両肺野部に長方形 の関心領域 $(\mathrm{ROI})$ を設定した。 ROIの寸法は30 (幅) $\times 120$ ピクセル (長さ)である。このROI内のピ クセル值のヒストグラムを作成し，ヒストグラム の最大值の $10 \%$ の高さに拈けるヒストグラムの 幅を測定し(Fig. 2)，その領域内のピクセル值の

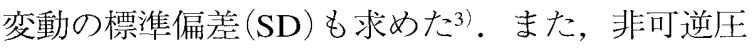
縮の影響によるノイズを比較するために，縦隔部 にもROIを設定し，その領域内のSDを求めた (Fig. 1).

4) 100 症例の臨床画像に対して, 経時的差分画像の アーチファクトの程度扮よび粒状性を主体とした 画質評価を行った．観察者は，4名の放射線技師 である。画像の観察は，オリジナル画像および 圧縮された画像から得られた経時的差分画像を CRTモニ夕(解像度; 水平：1,600ドット, 垂直： 1,200ライン，画面サイズ：20インチ，モノクロ） を用いて，同時に2画像表示して行った。また， 差分画像の輝度とコントラストは，ウィンドウと レベルを変えてそのつど調節を行った。

差分画像のアーチファクトに関しては, 過去お よび現在画像間の不整合に起因するアーチファク 卜を基準とした経時的差分画像の画質は, 非常に 


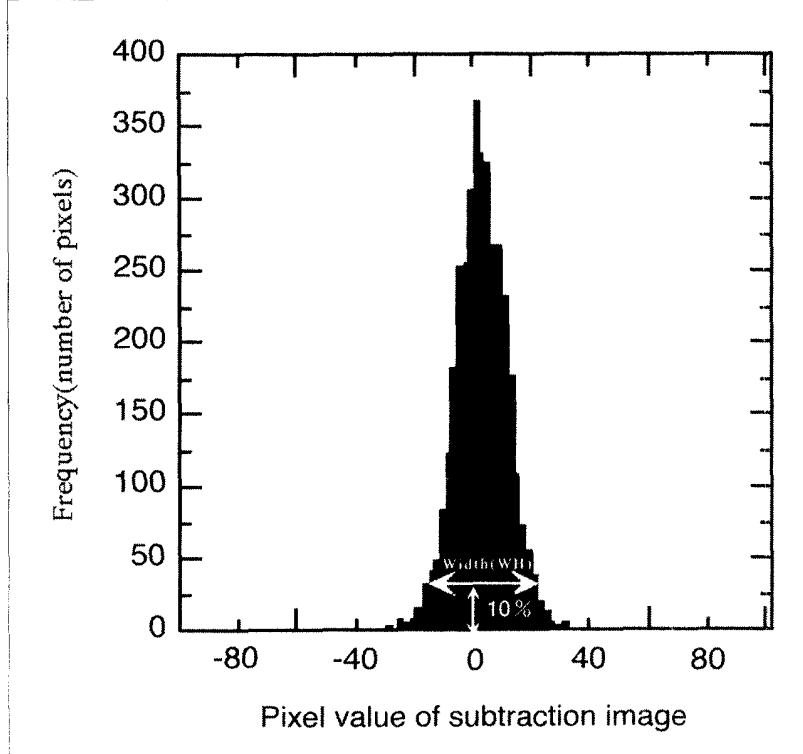

Fig. 2 Histogram of pixel value within the ROI selected in the right lung of subtraction image shown in Fig. 1.

良い，良いおよび悪いの3 段階で評侀を行った。 粒状性に関しては，オリジナル画像を用いたとき の差分画像を基準として 3 段階 $(-1$ ：厌絎画像が 劣る， 0 ：同等， +1 ：優れている)で詐㑣を行っ た。

5）人体胸部ファントムの前後に模擬腫瘤を貼付して 撮影した画像を現在画像とし，また，人体胸部つ アントムのみを撮影した画像を過去酸像として， 両画像間で差分処理を行った．使用した人体胸部 ファントムは，PBU-S-3株式会社京都科学製であ る。撮影条件は，臨床で使用した100kVの管電压 で，6.4mAsを用いた8)。今回使用した模擬腫溜は 球状で，これらの腫瘤のCT值(HU)の平均は47.1 の材料(石瞼)を使用した10)。Fig. 3は胸部ファン 卜ムに模擬腫瘤を付加した胸部画像上の腫溜の位 置を示す。その配置は肋間にある腫瘤が 4 個， 胁骨に重なる腫瘤が 4 個，心藏掞よび縦隔部に重 なる腫瘤が4個である。1回の撮影では同じ寸法 の模擬腫瘤を貼布し，使用した模擬腫瘤の直径は 4，5または $6 \mathrm{~mm}$ である。また，サンプル数はそ れぞれ $10 ， 10$ 抢よび5画像で，推察者は，4名の 放射線技師である。経時的差分画像の観察はCRT モニタを用いて行った。また，等分画像の輝度と コントラストは，ウインドウとレベルを変えてそ のつど調節を行った。評洒方法は，雄察者にはあ らかじめ腫瘤影の場所を知らせておき，3段階 (0：腫瘤は検出不可能，1：どうにか検出でき る，2：検出可能)で評佃を行った4).

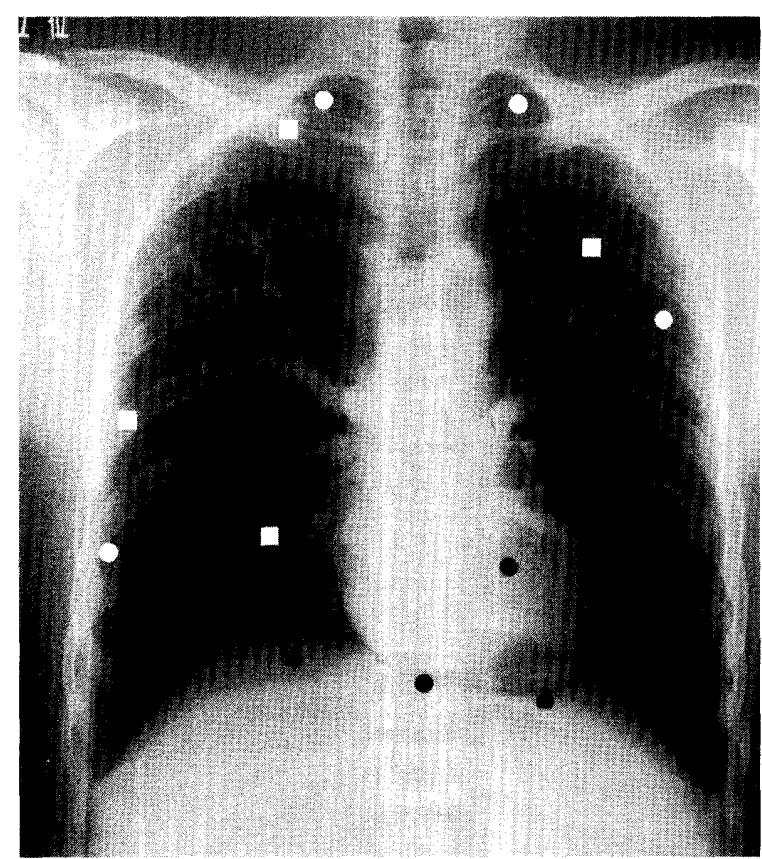

Fig. 3 Illustration of locations of simulated nodules on the phantom image.

$(O$ : nodules in the intercostal space, $\square$ : nodules overlapping with rib, 0 : nodules in mediastinum)

\section{2. 結 果}

Fig.4に，オリジナル徆像抢よび非叮逆压縮された

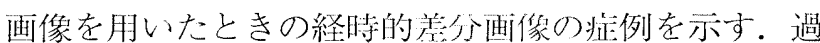
去抢よび現在画像間の不整命心起狋るア一チファク

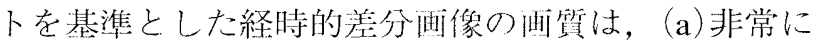

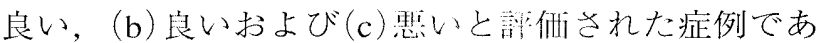
る。それぞれのROI内のピク七ル仙のヒストグラムの 幅は，50，100および180であった

四から分かるように，非问近压維によって肺野部画 像が影響を受けるようなことは諗められなかった。才 リジナル画像および非可逆王維された画像を用いた経 時的差分処理画像の闻肺野部に設这したROI内部のピ クセル值のヒストグラムの幅在Fig. 5に示す。両肺野 部の不整合に起因するアーチォァクトの程度を示すと ストグラムの幅は，ほぼ同等であのたが，压縮された 画像の方がわずかに四の左卜方に分布していた(Fig.

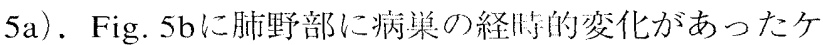
一スのヒストグラムの幅を小琼。の埸合，経時的差 分画像の濃度分布に変動が生じるためヒストグラムの 幅は広くなり，画肺野部のヒスト分ラムの幅は図の右 上に分布する。しかし，オリジナル画像および压縮さ れた画像から得られた差分洒像とも，アーチファクト の少ない画像であり，視覚的にも排逆王綃による影 響はみられなかった(Fig. 6).

オリジナル画像および王縮画像老用いて得られた経 

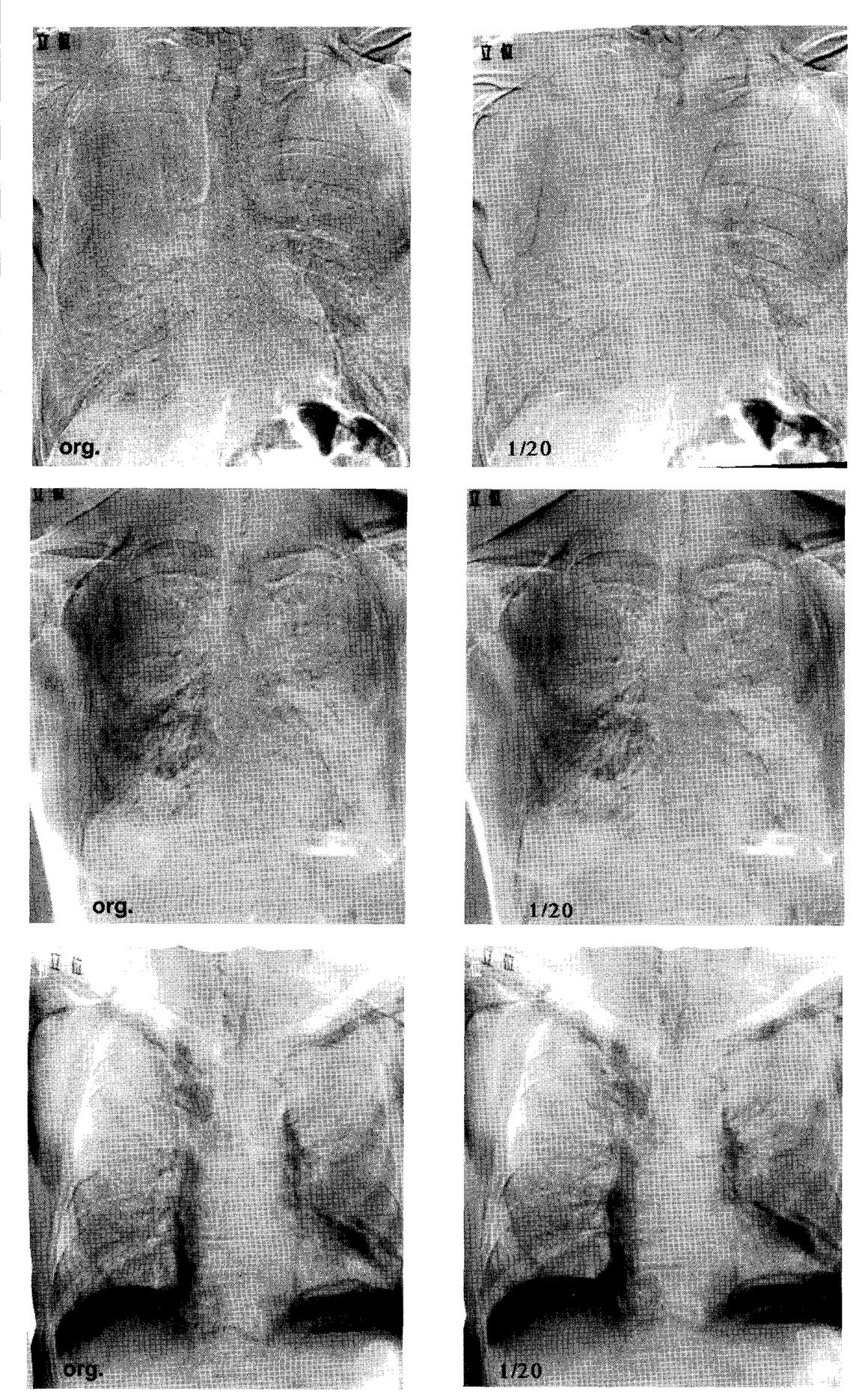

Fig. 4 Subtraction image obtained from original images and compressed images.

(a) excellent subtraction, (b) good subtraction, and (c) poor subtraction.

a

時的差分画像の，右肺野，左肺野および縦隔に設定し たROI内のピクセル值の標準偏差をFig. 7に示す。両 肺野部では，非可逆圧縮によって標準偏差はほとんど 影響を受けないが，縦隔部では，圧縮画像から得られ た差分画像の標準偏差が，オリジナル画像から得られ た差分画像よりも低下した。したがって，非可逆圧縮
は肺野部のノイズにはほとんど影響を与えないが，縦 隔部のノイズを減少させることが示唆された。

Fig.8は, 非可逆圧縮画像から得られた差分画像の 視覚評洒を示す。肺野部においては，非可逆圧縮によ る影響はなかった。縦隔部，横隔膜下部の評価では， オリジナル画像を基準にすると圧縮された画像が“優 


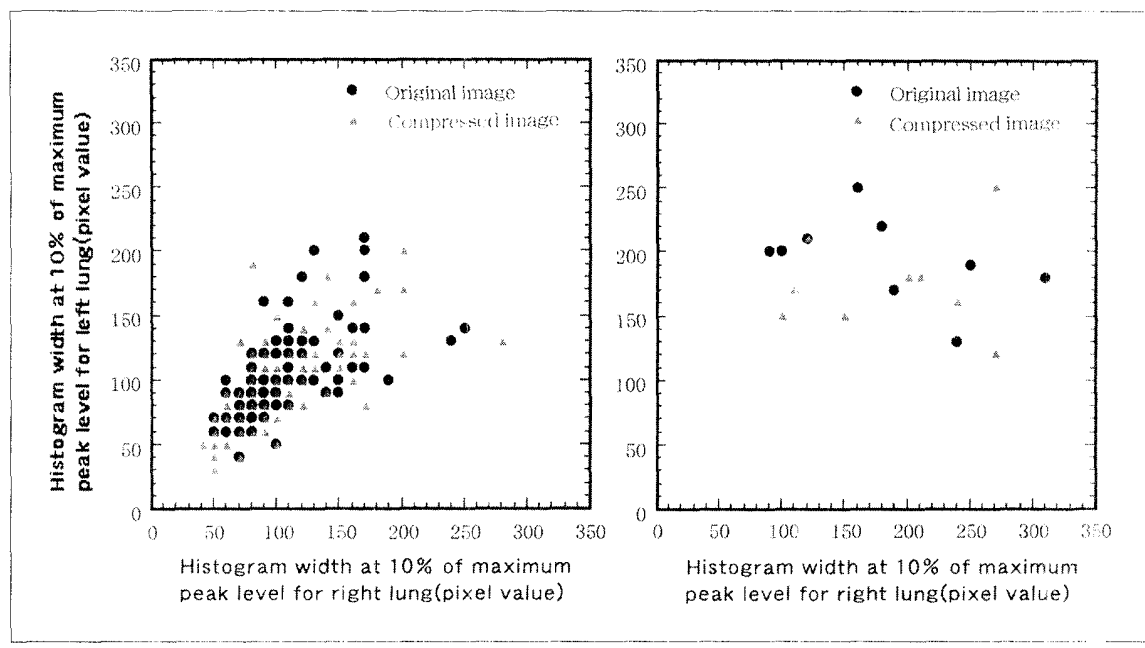

Fig. 5 Distribution of histogram width in lung fields of subtraction image obtained from original and compressed images.

(a) histogram width for cases without interval changes $(n=91)$,

(b) histogram width for cases with interval changes $(n=9)$.
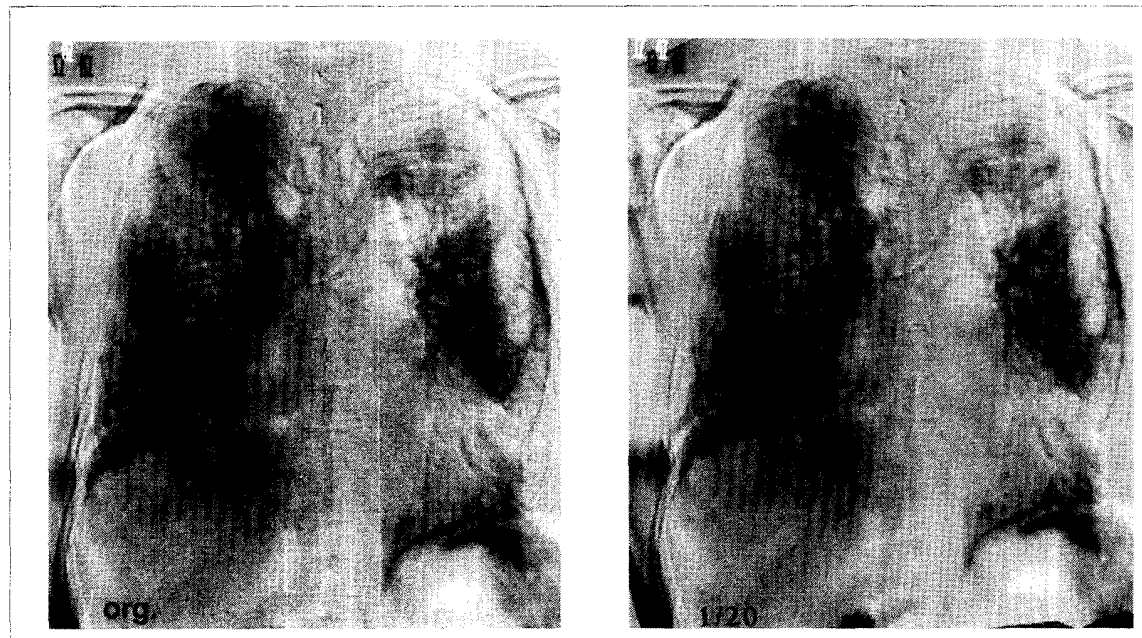

Fig. 6 Subtraction images obtained from (a) original and (b) compressed images with interval changes.
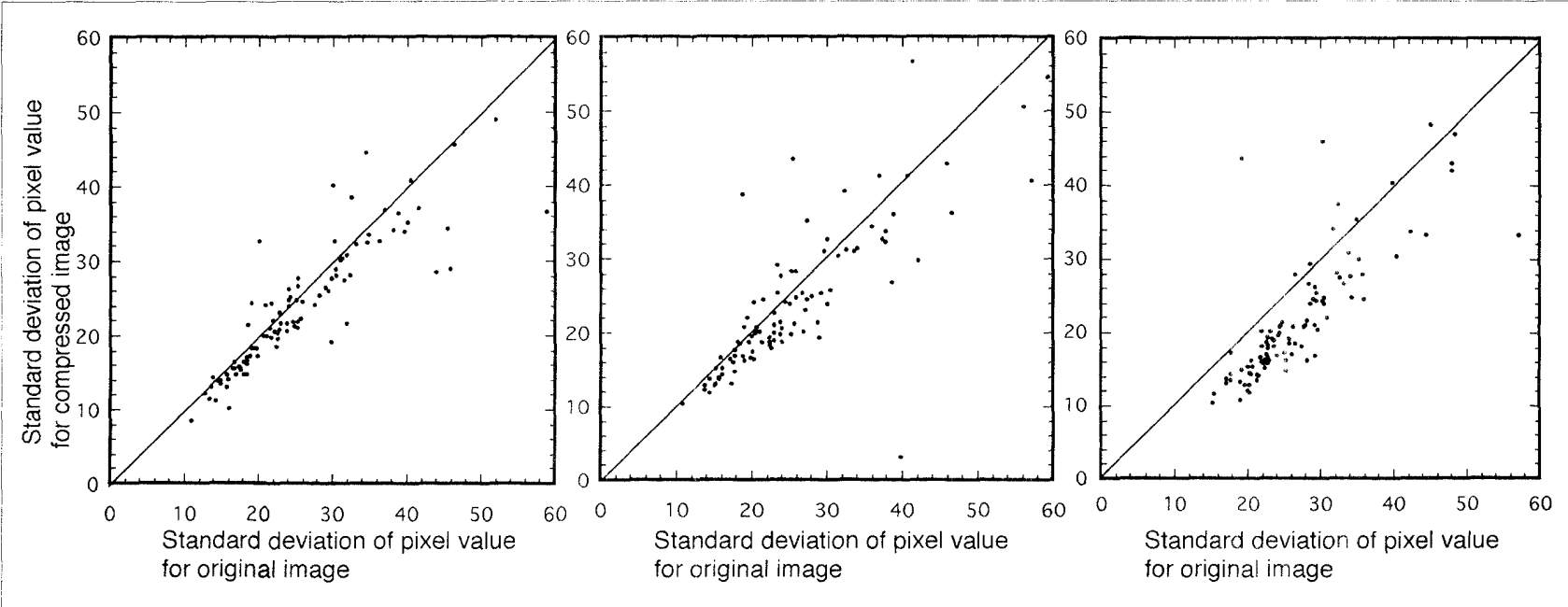

Fig. 7 Distribution of the standard deviation of the pixel value on the subtraction images. (a) right lung field, (b) left lung field, and (c)mediastinum. 


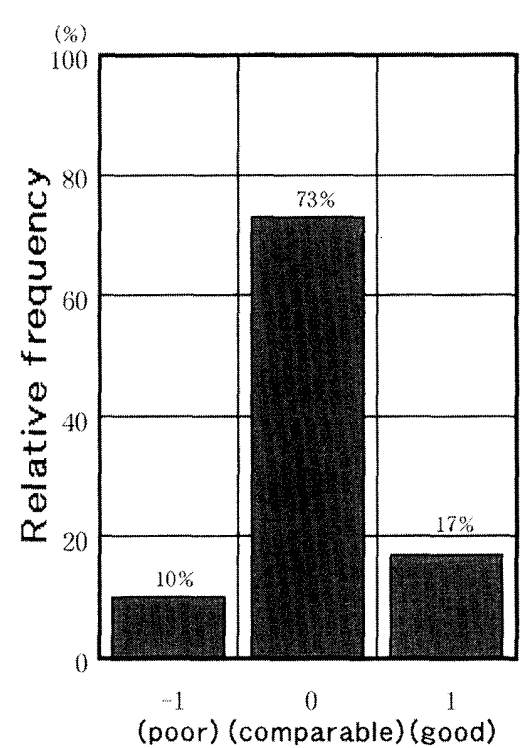

Subjective rating

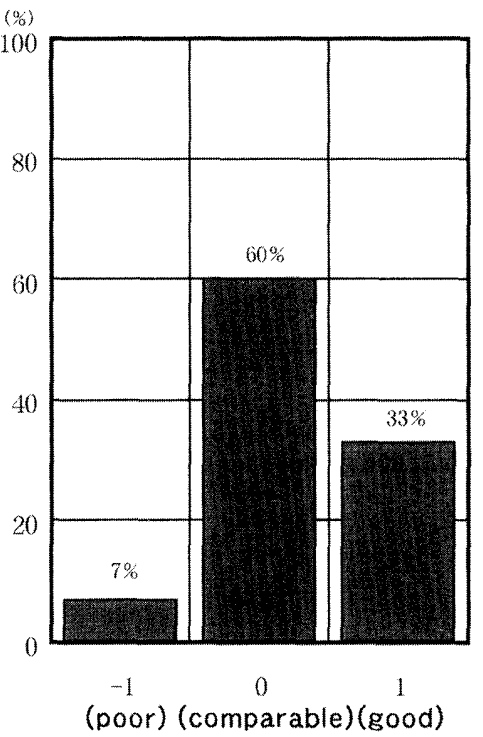

Subjective rating

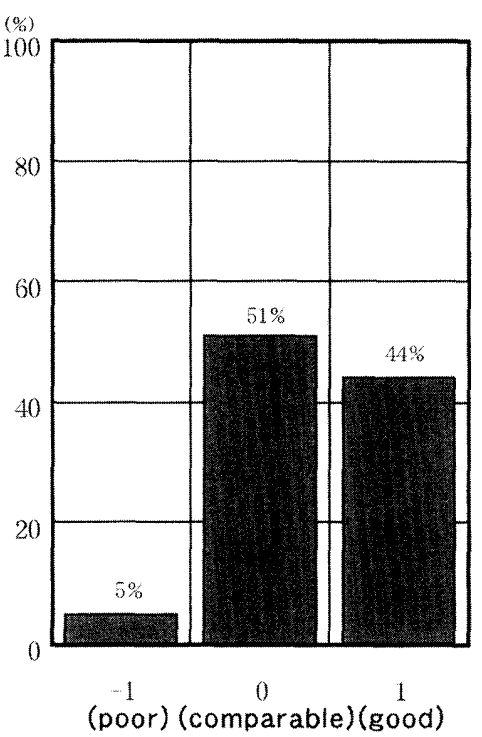

Subjective rating

Fig. 8 Subjective evaluation of the image quality of subtraction images (a) lung fields, (b) mediastinum, and (c) diaphragm.

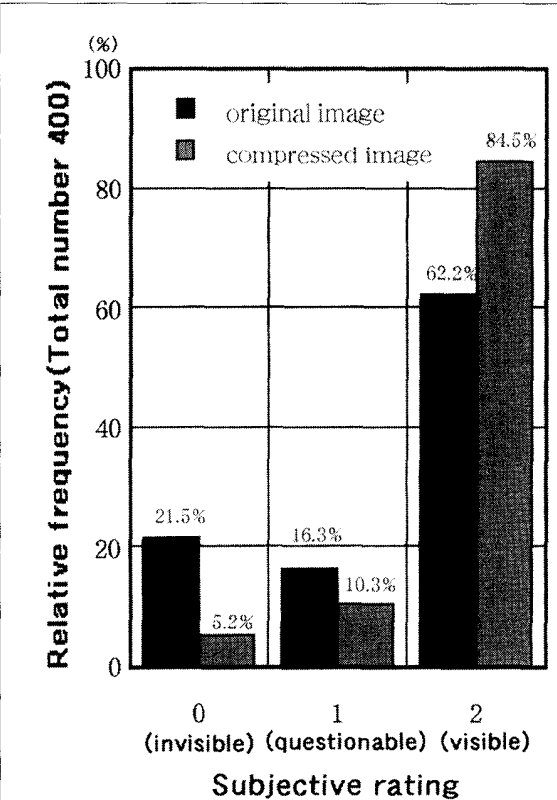

Subjective rating

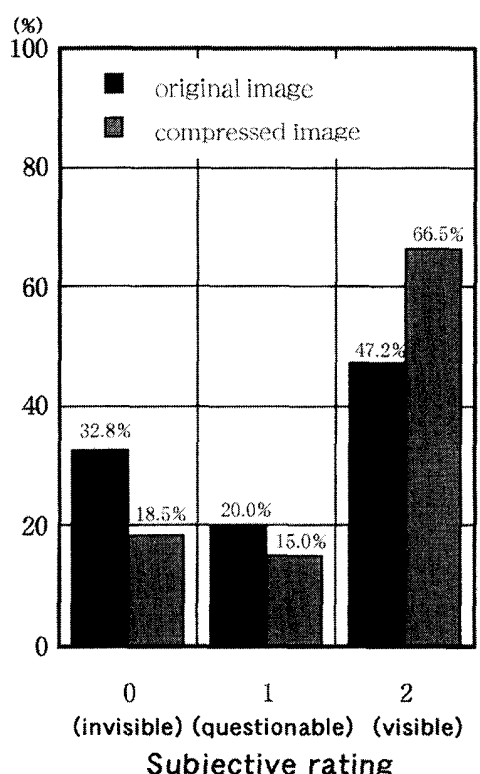

Subjective rating

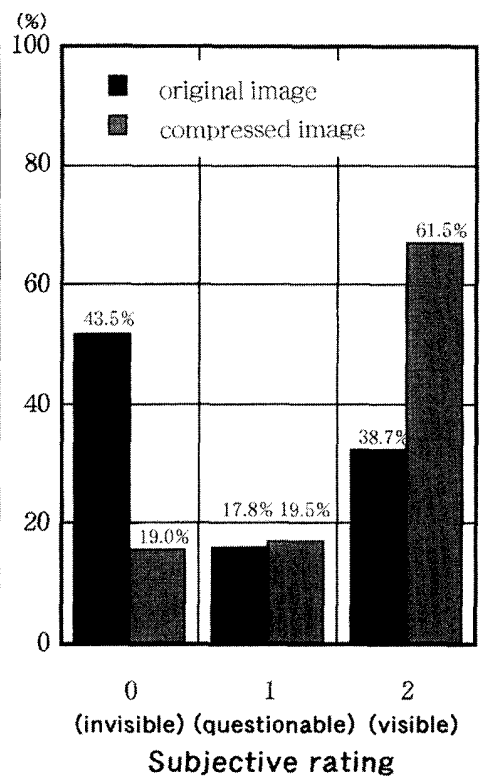

Fig. 9 Comparison of visibility of simulated nodules on temporal subtraction images using a three-point rating scale.

Simulated nodules are located (a) in intercostal space, (b) over rib, and (c) in me$a|b| c$ diastinum.

れている”は，それぞれ $33 \% ， 44 \%$ となり，非可逆圧 縮することによって画質の改善がみられた。

Fig. 9は，4～6 $\mathrm{mm}$ の模擬腫瘤の検出について，才 リジナル画像抢よび圧縮された画像を用いた差分画像 の 3 段階評価の結果を示す。オリジナル画像に比べ压 縮された画像の模擬腫瘤の“検出可能”と“どうにか検
出可能”を合わせたときの検出率は，肋間にある腫 瘤，肋骨に重なる腫瘤，心臓および縦隔部に重なる腫 溜において，それぞれ16.3\%，14.3\%および $24.5 \%$ と 向上した，特に，圧縮された画像における腫瘤検出の 改善度は，心臓および縦隔部に重なる腫瘤の場合が大 きかった。 


\section{3. 考察}

100 症例のオリジナル胸部CR画像と玨縮された画像 (1/20非可逆圧縮画像)のデー夕を用いて, 経時的差分 処理を行い，差分画像(マトリクスサイズ：586×586) に及ぼす非可逆圧縮の影響について検討を行った。そ の結果, 両肺野部のヒストグラムから求めたピクセル 値のマッチングの程度㧍よび視覚竍洒は, 非可逆王縮 による影響はほとんどなかった。しかし，縦隔部で は, オリジナル画像に比べて, 压縮された画像から得 られた差分画像は，ピクセル值の標潐偏差が小さく， ノイズが減少し，視覚的にも粒状性が改悲された。

これらの理由は，CRにおける画像ブー夕の圧縮方 式の影響が考えられる。オリジナル面像は1/2仃逝理 縮から復元された画像であり, その压縮方式は, 前值 予測とハフマン符号化を行って在縮守る方式である。

一方，1/20非可逆圧維は，2×2マトリクスのピクセル 値を平均圧縮した後，主デー夕と補間デー夕に分離 し，前值予測と八フマン符号化を行って压繀导る方式

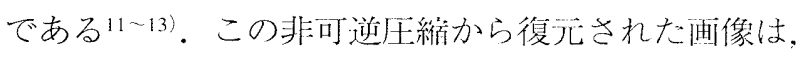
ピクセル值を平均王縮することによりオリジナル画像 に比べて, 高周波成分が減少している。一般に, 胸部 画像の縦隔部求よび横隔膜下部は, 肺野部に比べてIP 入射線量が少ないため，X線晴子モトルの増加により 粒状性が悪化している。しかし, 高鬥波成分が減少し た圧縮された画像は，この粒状性の増加を抑えて，経 時的差分処理画像のノイズ成分を軽減させたと考えら れる.このため, オリジナル涌像に比べて，代縮され た画像の縦隔部と横隔膜下部での画質の評俩は改良さ れる。

しかし、オリジナル画像と止縮された画像の肺野部 では，視覚的評伍に差がなかった。これは，肺野部は IP入射線量が多いため，ノイズ成分が少なく，もとも と粒状性が良い。したがって，非问逆区縮に上る影響 を受けにくく、オリジナル画像と区縮された画像の画
質の評価に差がなかったと考えられる。さらに，ワー ピングを用いた経時的差分酒像の帅野部の画質には, 細かな肺血管のマッチングがより大きな影響を与える が, 大まかな構造しかない縦隔部ぜ横隔膜下部ではノ イズが扮もな要因となる。したがって, 非可逆圧縮に よってノイズが減少することにより, 縦隔部抢よび横 隔膜下部での画質が改善されたと考えられる。

压縮された画像を用いた経时的分処理画像に打け る, 人体胸部ファントムに监驸された模擬腫瘤の検出 率は，心藏拉よび縱隔部に重なる壦命が最も向上した (Fig. 9).

この理由は, 压縮された泫像のうが縦隔部㧍よび横 隔膜下部の粒状性が良いため, CRTモニタ上で模擬腫 瘤の検出しやすい輝度とコントラ久トに増強すること ができ，検出㻭が高くなったためである。

\section{4. 結 語}

オリジナル画像と圧縮された画像 (1/20非可逆圧縮 画像) の胗部CR画像デー夕老䏘いて, 経時的差分処理 画像に及ぼすCRの非可逆画像梳維の影響について検 討を行った。

過去㧍よび現在画像の不整命に起因する, 雨肺野部 のアーチファクトは, 視覚評俩抢よびピクセル値のヒ ストグラムから求め大結果から, 非叮逆生縮に上る影 響はほとんどなかった。一う，縦缡割では，オリジナ ル画像に比べて, 圧縮された四像から得られた差分画 像は，ピクセル値の標淮偏差が小さくノイズが減少 し, 視覚的にも粒状性が改造された。したがって, 経 時的差分処理には, 非河近广維さ机た画像の胸部CR 画像データの使用が望ましい。

本研究は, 第56会総合学術大会(横浜)にて発表し た。 


\section{参考文献}

1) Kano A, Doi K, MacMahon H, et al.: Digital image subtraction of temporally sequential chest images for detection of interval change. Med Phys, 21 (3), 453-461, (1994).

2) Difazio MC, MacMahon $H, X u X-W$, et al.: Digital chest radiography: Effect of temporal subtraction images on detection accuracy. Radiology, 202 (2), 447-452, (1997).

3) Ishida T, Katsuragawa S, Nakamura K, et al.: Iterative image warping technique for temporal subtraction of sequential chest radiographs to detect interval change. Med Phys, 26(7), 1320-1329, (1999).

4) 小田敍弘，桂川茂彦，土井邦雄，他：胸部CR画像の経時的 差分画像による模擬腫瘤検出の改善。日放技学誌，55, 1101-1108, (1999).

5) 中村克己，魚住富淑弥，高橋広行，他：胸部単純X線写真 に扮ける経時的差分画像法の臨床的有用性. 日放技学誌， $56,496-502$, (2000).

6)柇上誠…，小田敍弘，寺田邦店，他：胸部と乳房のCR画像 におけるデー夕压維の検討。日放技学誌，51，13-18， (1995).
7) Mori $T$ and Nakata $H$ : Irreversible Data Compression in Chest Imaging Using Computed Radiography: An evaluation. Journal of thoracic Imaging, pp.1-8, Raven pres Ltd, New York, (1993).

8) Oda N, Nakata H, Murakami S, et al.: Optimal beam quality for chest computed radiography. Invest Radiol, 31 (3), 126131, (1996)

9) Oda $N$, Nakata $H$, Watanabe $H$, et al.: Evaluation of an automatic mode image processing method in chest computed radiography. Acad Radiol, 4 (8), 558-564, (1997).

10)村日暿代过：超高速CTの基礎と監床，肺野結節，pp.137147，金芳堂，京都，(1997）.

11 ) 和気治雄，川四明敏，楜澤淳一，他：FCR光ディスク画像 ファイリング装置の画像止縮の検討。第47回日本放射線技 術学会抄録, 1406, (1991).

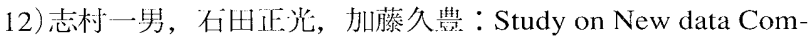
pression Method for CR image. 第46回日本放射線技術学 会抄録, 988, (1990).

13)石开正光，加藤久豊：CRシステムの機能と使いう。映像 情報 (M)，6，97-101，(1989）。

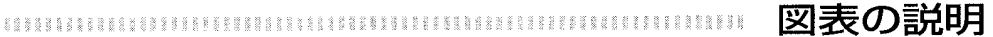

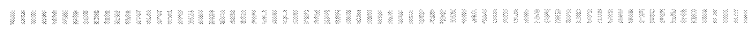

Fig. 1 経時的差分画像の両肺野部と縦陾部に設定したROI.

Fig. 2 経時的等分画像(Fig. 1)の不肺野部のROI内のピクセル値のヒストグラム.

Fig. 3 ファントム画像に抢ける模挨腫瘤の位置.

(○：肪間にある腫瘤， $\square$ ：肋筒に重なる腫瘤，

：心臟および縦隔部に重なる腫瘤）

Fig. 4 オリジナル画像(左)㧍よび非可逆圧縮された画像(右)から得られた経時的差分画像。画像は，(a)非常に良い，(b)良い， (c)要い，と評洒台れた。

Fig. 5 兩肺野部に㧍けるヒストグラムの幅の分布.

(a) 経時的変化がなかったケース $(n=91)$ ，（b) 経時的変化があったケース $(n=9)$.

Fig. 6 経㭙的変化があったケースの䋂時的差分两像.

(a)オリジナル画像，（b)非可逆圧縮画集.

Fig. 7 経時的姜分画像におけるピクセル值の標準偏差の分布。

(a) 右肺野部, (b) 左肺野部, (c) 縦㜔部.

Fig. 8 経時的差分画像の画質評価.

(a) 肺野部，（b) 縦陑部，（c) 横陾膜下部.

Fig. 9 経時的差分画像の三段階詊価による模指腫瘤検Hの比較.

(a)肋間にある腫瘤，(b)肋查に重なる腫瘤，(c)心臓㧍よび縦隔部に重なる腫瘤. 